\title{
Gender Role Beliefs at Sexual Debut: Qualitative Evidence from Two Brazilian Cities
}

CONTEXT: Culturally based beliefs about gender roles influence women's sexual behavior and their ability to protect themselves from unwanted sexual experiences. Studying the beliefs that influence women's behavior at sexual debut helps contextualize unwanted sexual intercourse.

METHODS: Twenty-four focus groups on women's beliefs about gender roles at sexual debut were conducted in 2002 with low-and middle-income women aged 18-21 and 30-39 who were recruited from public and private venues in Recife, capital of Pernambuco, and Belo Horizonte, capital of Minas Gerais, Brazil. The data were analyzed for common themes, and quotations were chosen to illustrate those themes.

RESULTS: Focus group participants perceived that men have an urgent need for sex. This perception caused women to fear abandonment, anger or violence if they refused to have sex with their partner. The participants believed that women had to act passive the first time they had sex because taking the initiative (for example, by asking their partner to practice contraception) would lead him to accuse them of having previous sexual experience. Also, they believed they had to say no to sex under all circumstances to protect their reputation.

CONCLUSION: To decrease the occurrence of unwanted intercourse, interventions must address the social expectations that influence men's and women's sexual behavior.

International Family Planning Perspectives, 2006, 32(1):45-51
By Ann M. Moore

Ann M. Moore is senior research associate at the Guttmacher Institute, New York.
The great majority of reproductive health research assumes that, except in the case of rape, sexual intercourse is voluntary and wanted. Although the Demographic and Health Survey (DHS) questionnaire asks whether the intercourse reported by a woman was involuntary, it does not ask if the intercourse was wanted. Researchers have found that rape accounts for only a small percentage of women's experiences of unwanted sexual intercourse. ${ }^{1}$ In fact, many experiences that are not categorized in surveys as involuntary take place according to the man's dictates, without regard for the woman's desires. These unwanted experiences are shaped by beliefs about gender roles and clouded by ambiguous communication.

Sexual negotiation and communication take place within the context of culture-based beliefs about sexual functioning. Therefore, identifying these beliefs is critical to understanding how and perhaps why control is or is not exercised by women. Brazil provides an interesting case study of sexual experiences because its culture is traditionally patriarchal, grounded in Catholicism and machismo, and yet in juxtaposition to these generally repressive doctrines, Brazilian women are seen as very sensual. Nevertheless, Brazilian women's voices regarding their own sexual desires and experiences are largely missing.

The meaning of sexual intercourse changes significantly over the life course. In order to deal with moderately comparable events, this study focuses on women's first vaginal intercourse when it occurs outside of marriage.

\section{BACKGROUND}

While in the pursuit of other research interests, a number of investigators in Brazil have found evidence of negative sexual experiences for women. For example, in their evaluations of HIV-prevention campaigns with adolescents, Monteiro in Rio de Janeiro and Paiva in São Paulo demonstrated that condom distribution campaigns were having little effect on the spread of HIV because the campaigns were grounded in a concept of equality between the genders that did not match the adolescents' reality. ${ }^{2}$ Other studies have indirectly documented the burden of unwanted sexual intercourse in Brazil while examining women's strategies to avoid sex. Women in focus groups in São Paulo reported that men accepted headaches, menstruation, toothaches, general preoccupations and fatigue as reasons for refusing sexual intercourse, and said that they used these "acceptable" excuses with frequency. ${ }^{3}$ Brazilian women also employ folklore-based reasons to abstain from sex. Breast-feeding women refused sexual advances by stating that semen would poison the breast milk. ${ }^{4}$ Some women feigned menstruation, using the social taboo against sexual intercourse during that time. ${ }^{5}$ Women in Pernambuco, noting rumors that tubal ligation induces frigidity, said that having the procedure would provide them with a welcome strategy for avoiding unwanted intercourse. ${ }^{6}$ Yet respondents in one study believed that using excuses to avoid intercourse should have limits and explained that they observed certain rules when using these excuses. One middle-class participant said, "If 
I say I have a headache, he understands.... But if we always say no, we'll lose our husband[s]" [author's translation]. ${ }^{7}$

In Brazil, one's sexual debut marks the transition to womanhood. Virginity has lost much of its social value in the middle- and upper-class cultures of São Paulo and Rio de Janeiro, but it continues to be relatively important in more rural areas and among the lower classes. The 1996 Brazilian DHS showed that $1.2 \%$ of women reported that their sexual debut was involuntary $(4.1 \%$ for women younger than 15 years old, $0.4 \%$ for women $15-17$ years old and $0.0 \%$ for women $18-24$ years old). ${ }^{8}$ However, involuntary sexual debut captures only a small proportion of all unwanted sexual debuts. Of 45 sexually active women aged 14-17 interviewed in a midsized city in Minas Gerais, five said they neither liked nor disliked their sexual debut, four disliked it and six had not wanted to have sexual intercourse at that point in time. ${ }^{9}$ Fear, suffering, sadness, anger, savage and bad were some of the words used by women to describe their first intercourse experience (vaginal or anal). These studies demonstrate that women's agency at sexual debut in Brazil demands further attention.

\section{DATA AND METHODS}

Studying female sexual agency at sexual debut requires relying on participants' accounts of their experiences since the event under study is by its very nature hidden. Furthermore, the event is always recounted retrospectively, introducing the bias inherent in recall. Therefore, I used focus groups to capture what women perceive as normal at sexual debut. While negotiation can involve contraceptive use or what sexual behaviors to engage in, this article deals with the negotiations regarding whether to engage in sexual intercourse. This study focuses on women's experiences of premarital sexual debut; in 1996, the date of the last Brazilian DHS, 84\% of initial sexual experiences for women 15-24 years old took place before marriage. ${ }^{10}$

This study was conducted in 2002 in Belo Horizonte, the capital of the state of Minas Gerais, and Recife, the capital of the state of Pernambuco. Both cities are large metropolitan areas - the fourth and eighth largest cities in the country, respectively. With approximately $80 \%$ of Brazil's population residing in cities, 10 of which have more than a million inhabitants, it was fitting to carry out an urban study. The two cities provide an interesting comparison between the wealthier, industrial southeast (Belo Horizonte) and the more impoverished, agrarian northeast (Recife). Participants were recruited at locations where they lived, worked or obtained services within the city limits of the two sites. Respondents were recruited from public health posts in slums, college preparatory facilities, community activity centers, university classes and personal networks. Within each city, the sample was divided between lower-income and middle-income, as well as 18-21-year-olds and 30-39-year-olds to capture the sexual experiences of two different generations. The focus groups were stratified according to socioeconomic status and age to maintain homogeneity within groups. Socioeconomic status was based on self-reported neighborhood of resi- dence and age. The 18-21-year-olds had completed an average of 10.2 years of education and had 0.2 lifetime births per woman at the time of participation; the 30-39-year-olds had completed an average of 9.9 years of education and had 1.6 lifetime births per woman. Most of the participants were white or mixed race, with a minority identifying as black. Institutional review board approval for fieldwork was obtained from the University of Texas at Austin.

All of the focus groups took place in Portuguese, and were moderated by a native speaker as the author observed and took notes. After the guidelines had been pilot tested and the questions modified accordingly, 24 focus groups were held-12 in each city, with an average of six participants each. On average, the focus groups met for two hours. All discussions were tape-recorded and later transcribed by a native Portuguese speaker, and all of the analysis was done in Portuguese. The software program NVIVO2 (QSR International, Melbourne, Australia) was used for the data analysis to identify major themes related to agency and control at first sex. The author created the codes, coded the data and analyzed the data. The key themes are summarized below, illustrated with quotes. The quotes that appear below were translated by the author and were not back-translated. The moderator is designated by the letter $\mathrm{M}$ and the various participants by P, P1, P2 and so on.

\section{RESULTS}

\section{Women's Perceptions of Male Sexual Behavior}

Women's perceptions of men's sexual needs and how men would likely react if those needs were not met are a critical aspect of the sexual interaction. The most prevalent belief held by women was that all men need sex and would therefore abandon a woman, or in some instances resort to violence, if she did not agree to have sex.

- The male need for sex. One of the most common assumptions voiced by the women was that men need frequent sexual activity.

P1: Men want sex all the time, you know?

P2: And when he wants it, we have to give it to him.

-lower-income 18-21-year-olds, Belo Horizonte

Even when a man expressed a willingness to wait for sex, respondents were distrustful.

P: Look, the majority of men are scoundrels.... I don't trust my boyfriend. I love him, I think he's the man of my life. And I say to him that I don't trust him. I know that he could find another woman, you know? ... So even though he tells me that he'll wait [until I want to have sex] and tolerate me and give me what I want, I want to believe him but women have fears. I have fear. Now I'm really scared that he'll find someone else to satisfy him, you know?

\section{-lower-income 18-21-year-olds, Belo Horizonte}

For some participants, the belief that men need sex meant that they tolerated an unfaithful partner in order to preserve their virginity.

P1: I said no to him. "No, let's wait till we're married."

P2: He threatened you, didn't he? 
P1: Yeah, he really did. He got tired of threatening me. He'd leave me at home and go looking out on the street [for a prostitute].... But, as they say, love is blind, right? He'd go looking for his women in the street and...the following day, he'd be at my house, hugging me and kissing me.

P3: And he knew that you knew that he'd looked for another [woman]?

P1: He knew. He's the one who told me.

M: What would he say?

P1: He'd say to me, "Since you don't want to give it to me...."

P2: What happened was that you were scared of losing him, the loss. Sometimes, lots of times, you're with a guy, sometimes you like him so much but sometimes because of the threats, you are scared to lose him, and there's where you give in.

P1: But I fought all the time with him. I said, "You go take a bath in alcohol from your head to your toes" [because you've been with a prostitute].

-lower-income 30-39-year-olds, Belo Horizonte

P: He wanted to pass the limit with me and I said, "No...this way, we're going to have to break up because I am a moça [virgin]." So sometimes he looked, for example, for a woman in the street. He wanted to do to me, a moça, what he did with those women in the street. I said, "No, you'd better go find a woman in the street because I'm a moça. If you want to date me direito [correctly], you respect me, don't pass the limit."

-lower-income 30-39-year-olds, Recife

That the partners of the participants quoted above were having sex with other women did not seem to challenge the participants' place in the relationship. Rather, this was a way for women to maintain their virginity in the face of men's perceived need for sex. Although the belief that men need sex was a near-universal theme across all the focus groups, lower- and middle-income 18-21-year-olds from both cities challenged the legitimacy of this idea.

- The threat of abandonment. The fear of being abandoned for another woman was the reason most frequently cited for engaging in sexual intercourse by the participants in both cities and across socioeconomic and age divisions.

M: Why did she [a friend] have sex?

P: She liked him and wanted to stay with him no matter what. She thought that this was a good idea... She did it to satisfy him. She didn't think about her own pleasure. She had sex to hold on to him. [She thought:] "If I hold on to him in bed, he's mine. He won't go looking for someone else." -lower-income 18-21-year-olds, Belo Horizonte

P: Women are very scared. I think that they are very scared, very insecure. They think, "If I don't [have sexual intercourse], I will lose him, whom I like so much.” ... Many women start thinking, "If I don't, he will think that I'm really slow... and he won't want to talk to me anymore, won't want to see me anymore."

-lower-income 18-21-year-olds, Recife

P1: It's because women think like this, "Gosh, if I say no to him, he'll get upset," because there are lots of women who are scared of losing the guy they like.... Lots of women pass through this. [They think:] "If I say no to him, he'll leave me, so I'll do what he wants."

P2: Out of fear of losing him.

-middle-income 30-39-year-olds, Recife

Although respondents said men do threaten to abandon their partners, women often had sex out of fear of abandonment even when the men did not voice any explicit threat.

- Fear of the male reaction to sexual denial. Another prevalent belief among the respondents was that sexual denial would provoke a man's anger.

M: Do women think about what the guy will do if they say no when things are progressing to sexual intercourse?

P1: She gets scared. [She thinks:] "Gosh, I'll... what will I say?" He'll get angry.

P2: [She thinks:] "He'll get angry at me."

P3: [She thinks:] "And he won't look in my face any more." So she gets scared. This happens a lot.

P4: It's difficult.

P5: Many [women] don't end things [the sexual encounter]; they let it roll so that he doesn't get angry.

-middle-income 18-21-year-olds, Recife

Fear of physical violence was cited as a reason to engage in sex even if women did not want to. This fear was most often voiced by older, lower-income focus group respondents.

M: Women had fears in saying no?

P1: Of being beaten up.

P2: Yeah.

P3: Of being beaten.

P4: Hit in the face.

M: Yeah?

P5: The men of this time hit women a lot.

M: Hit them?

P5: Hit them.

-lower-income 30-39-year-olds, Belo Horizonte

M: Why is it not possible to say no?

P1: It's because we know the temperament of our partners. So a woman won't say no because she knows that he will react in an aggressive manner.

P2: There's that fear that you'll be attacked....

P3: It happens.

P4: It happens.

P5: It happens.

P3: And the force...

P2: ... of a man who's furious...

-lower-income 30-39-year-olds, Recife

Although lower-income participants were more likely than middle-income participants to relate having experienced violence or knowing someone who had experienced violence the first time they had sex, they were also more likely than middle-income participants to relate stories of women challenging men's attempts at forcing them to have sex.

Women anticipated abandonment, anger or violence as a consequence of not having sexual intercourse; this reaction was accepted and understood, largely, because of men's 
perceived need for sex. In Brazil, a man's support and protection greatly increases women's access to social status, financial well-being and protection from other men's sexual advances in the public sphere. ${ }^{11}$ Satisfying a man's sexual desire is a strategy women employ to increase their chances of keeping a man around.

\section{The Accommodating Woman}

The dynamic at sexual debut is only partially explained by looking at women's expectations of male behavior. Women's expectations of themselves are equally important. The beliefs about female behavior that emerged from the focus groups were largely grounded in men's perceived expectations of women's behavior.

The most prevalent opinion voiced by the respondents for women at sexual debut is that they should be completely passive and ignorant. If women behave otherwise, they risk being accused of having previous sexual experience. Women also believe they are expected to say no to sex under all circumstances so as not to be seen as looking for sex. Latin America's conservative Catholic tradition ties a woman's status to her perceived sexual purity. This idea lives on in contemporary Brazil: The participants in these focus groups used the terms meninas para namorar ou meninas para casar [girls to date or girls to marry] to draw the distinction between girls with good reputations and those with bad ones.

-The need to act passive. Lower-income participants of both age-groups and in both cities voiced the unequivocal belief that women should act ignorant about sexual functioning and, as a result, be passive at sexual debut. It is not acceptable for women to make sexual advances, ask for the use of contraceptives or demonstrate any sexual knowledge.

P1: I think it's very rare for women to take the initiative.... I think the majority depend on his initiative. No matter how much they [women] want to, no matter how much they are willing, there is always that threat of what the man would say. P2: What he'd think of you, because if you were doing that with him, you already had other experience.... They always want to be the first, and the fact that the woman took the initiative would stick in his head.

-lower-income 30-39-year-olds, Recife

From the women's perspective, passivity was appropriate, in part, because men always had more sexual experience than they did.

P1: Men always had sex, starting from age $12 \ldots$

P2: Even the parents would take him to the Zona [area of prostitution] to be a man.

P3: It was like, women were like this, "You have to be a sinhazinha [delicate and beautiful lace edging], put together." In this way, men were much better developed than we were. We learned things [about sex] late in life. Men already knew how to do it.

-lower-income 30-39-year-olds, Recife

To take sexual initiative, which includes dressing in a sexually suggestive way, places women at risk of jeopardizing their status as a menina para casar. Women eavesdropped to learn how men divided women into the categories of meninas para namorar or meninas para casar.

P1: At home, I'm the only girl. My brother's going to be 19, but he only hangs out with older boys. Like the cousins and stuff who are older, like 27, like 28. What I see of their conversations, there are two types of women. One of them has a girlfriend just like he likes it. And he has that one in the street who is more sem vergonha [shameless]. So there are still lots of boys who dream like this, that desire both types of women. Most guys are like that and they think they can have everything....

P2: Just like you see in the street, a woman walks by in little shorts and a plunging neckline, [the boys say:] "That's tasty." A girl walks by nicely made-up, [and the boys say:] "That's the woman of my dreams."

P3: Exactly.

\section{-lower-income 18-21-year-olds, Belo Horizonte}

This division is based on the assumption that a woman displaying her body has loose sexual morals and is consequently not someone to marry, only someone with whom to have sex.

P1: I have some really good guy friends and we talk about everything.... [They say:] "I will arrange to have many girlfriends, I will date all the girls, but I'll marry you." [Laughter.] They joke like that: "Because you're a girl to marry." Never would they take that girl that they make out with every day and marry her.

P2: Because she's not the kind of person that he wants for marriage. This happens a lot.

P3: He wouldn't have any confidence in her [fidelity].

-middle-income 18-21-year-olds, Recife

The extent to which virginity is socially valued varied greatly between the two age-groups studied, as well as by social class and education level. Being suspected of having had previous sexual experience could be emotionally searing and carry social consequences, such as losing one's status as a menina para casar. The majority of women spoke about how they had to engage in "image management" that ranged from not taking the initiative sexually to making sure that they did not display the signs that men interpreted as meaning that they were sexually experienced. Any initiative taken by women preempted the male conquista [conquest], another important part of the sexual interaction.

- Saying no to sexual intercourse. Rebhun found that in Brazil, moral accountability for sexual behavior still resides with women, who are expected to say no to sexual advances. ${ }^{12}$ Furthermore, a woman must say no to sex so the man can overcome her resistance. This attitude is grounded, in part, in the idea, as identified by Caravelas ${ }^{13}$ and later by Goldstein, ${ }^{14}$ of an inherent sensuality of women, more prevalent in Brazil than perhaps elsewhere, that makes it impossible for them not to want sexual intercourse. Zanotta Machado's male interviewees in Brazil treated no as a part of the seduction. ${ }^{15}$ Female focus group respondents in the present study described the importance of never acting willing to have sex at sexual debut. 
Lower-income participants across age-groups and cities described how the conquista happens.

P1: When a woman likes that person... a woman has that history of prohibition against expressing her desire. We're very much blamed, everything is prohibited for women, so we have this history of prohibition against expressing our desire- "No, no, no" [while grabbing the woman next to her in a sexually suggestive way] — saying no is not a question of wanting...it's more that you want it, but you have to say no because... it's not that you don't want it, you are crazy with desire, you want it but you have to play this game, you have to make a little drama.... Like, "Get off me, get off me." [Laughter.]

P2: Even if she wants him to continue, for her to be conquered, she says, "No, no, no," and lets him come and grab her so that he doesn't think that she's easy, you know....

P1: On the other hand, it's not cool that we lose a lot of time blocking, in the end we're perpetuating a lot of things, lots of taboos that we have. In reality, you don't want to say no, you want to say yes and even take the initiative, but you see, there are the blame and accusations, the preestablished rules that you run into.

-lower-income 30-39-year-olds, Recife

P: My other boyfriend, he would come and I would reprimand him, "No!" Even if I was dying of desire, I said "No!" M: Oh, yeah?

P: It's that "No, yes," right?

-lower-income 18-21-year-olds, Belo Horizonte

Respondents would say no while demonstrating yesthat is, say no while suggestively touching the participant next to her. In a more animated focus group, a participant acted out saying no to her sex partner while she mimed riding a horse. These physical demonstrations always sent the respondents into peals of laughter as they recognized their own behavior in the actions of the other women. In spite of this, the majority of participants were very clear about the fact that rejecting sex was as simple as saying no.

Yet there is evidence that these prescripts may not be as absolute among the younger participants as they were among the older participants. Some lower-income 18-21-year-olds from Recife advocated both taking the initiative and engaging in token resistance to sex. The importance of saying no to provide an opportunity for sexual conquest did not play as prominent a role in the narratives of middle-income participants from Recife as it did in those of the lower-income participants.

\section{DISCUSSION}

The beliefs that women in Belo Horizonte and Recife, Brazil, hold about male and female roles in sexual behavior provide insight into the occurrence of as well as the circumstances of women's sexual debuts. Data such as those presented here challenge the implicit assumption of the majority of quantitative studies that first sexual intercourse, an oftused demographic benchmark, is a wanted and mutually agreed-upon experience in which partners have more or less equal control.
Pressure to engage in intercourse was a familiar aspect of sexual debuts among women of both socioeconomic strata and age cohorts and in both cities. This pressure was present in part because of the social perception that the male need for sexual intercourse is urgent and requires immediate gratification. The perception that a man would leave if not provided for sexually — even in adolescence-was treated by the focus group participants as inherent to masculinity and therefore socially legitimate. Anger and, less commonly, sexual violence from a man in response to sexual rejection, which came up more frequently in lower-income groups and among older respondents than among others, were also feared. Although some female participants in the present study did relate positive experiences at first intercourse and were able to satisfy their own sexual needs, this article focuses on the attitudes held by the majority of the focus group respondents in regard to male and female behavior in the context of a woman's sexual debut.

What is most striking about these findings is that the perception of negative consequences for not having sex with their partner was so pervasive that women felt pressure to engage in sexual intercourse even when their partner did not express any threat. The beliefs that men need sex and will abandon or abuse their partner if she does not provide it create an environment in which sexual coercion of women is the rule rather than the exception. Even if a man does express acceptance and understanding of his partner's desire to abstain from intercourse, it is difficult for the woman to believe that any one man could act counter to his "nature."

Coercion of women to engage in unwanted sexual intercourse has typically been assumed to occur through threats. ${ }^{16}$ However, Heise, Moore and Toubia ${ }^{17}$ point out that "the touchstone of coercion is an individual woman's lack of choice to pursue other options without severe social and physical consequence." To the extent that women engage in unwanted sexual intercourse because they believe their partner will otherwise abuse or abandon them even if no threat is made, they are experiencing sexual coercion.

Acting passive and inexperienced at sexual debut undermines women's ability to exert any control over the sexual situation. One of the justifications women used for acting passive at first intercourse is that men have more sexual experience. By engaging in sex with partners who have greater sexual experience, women are placing themselves at increased risk of exposure to STIs. Although fewer than $1 \%$ of Brazilian adults are estimated to be infected with HIV ${ }^{18}$ other STIs are common; Recife has the highest prevalence of human papilloma virus infection in the world. ${ }^{19}$

Saying no to sex under all circumstances also feeds the social belief that women's refusals of sexual advances are insincere and therefore need not be taken seriously. The participants did not acknowledge the contradictory messages they gave their partners by saying no both when engaging in token resistance to sex and when actually not wanting to engage in sex. However, even though saying no as part of token resistance may neutralize its meaning in an unwanted sexual situation, this script is a critical part of the

\section{Saying no to sex}

under all

circumstances

feeds the

social belief

that women's

refusals of sexu-

al advances are

insincere and

therefore need

\section{not be taken}

seriously. 
image management that women engage in to maintain their reputation

There is evidence that some of these beliefs about male and female behavior are in transition-younger respondents approved more progressive gender roles than their older counterparts. For example, some 18-21-year-olds in both cities and in both socioeconomic groups challenged the idea that men have an overwhelming need for sex. Some lower-income 18-21-year-olds in Recife said women should take the initiative sexually, yet they also advocated engaging in token resistance. The presence of both traditional and progressive messages may leave women unsure of how to behave.

Although these focus groups capture the experiences of individuals in only two locations in Brazil, women's lack of sexual assertiveness at first intercourse is not unique to the two study sites. The gender relations and social paradigms of behavior identified in this study are at play throughout Brazil and other Latin American countries. Therefore, these sites may serve as a case study of the control women expect to exercise at sexual debut in other contexts with similarly constructed gender roles.

Future analyses of sexual negotiation at first intercourse can benefit from an understanding of the role played by women's beliefs about gender relations and social behavior. It is critical that future research on sexual intercourse, not only at debut but throughout the life course, take into account the fact that women may be having sex out of fear because they are functioning under certain culturally informed assumptions that limit their ability to control the sexual situation. Women's vulnerability to unwanted sexual intercourse needs to be addressed, beginning with the gender roles that girls and boys learn at an early age. Sex education classes can also address gender roles in sexual relationships, through the way that contraception is presented to users, the way that users are taught to introduce contraceptives into a sexual relationship and the way that young people are taught about STIs. Fostering a more egalitarian model of sexual behavior that allows both women and men to choose whether to have intercourse will go a long way toward decreasing unwanted sexual experiences.

\section{REFERENCES}

1. Abma J, Driscoll A and Moore K, Young women's degree of control over first intercourse: an exploratory analysis, Family Planning Perspectives, 1998, 30(1):12-18

2. Monteiro S, Gênero, sexualidade e juventude numa favela carioca, in: Heilborn ML, ed., Sexualidade: O Olhar das Ciências Sociais, Rio de Janeiro, Brazil: Jorge Zahar, 1999, pp. 40-58; and Paiva V Gendered scripts and the sexual scene: promoting sexual subjects among Brazilian teenagers, in: Parker R, Barbosa RM and Aggleton P, eds., Framing the Sexual Subject: The Politics of Gender, Sexuality, and Power, Berkeley, CA, USA: University of California Press, 2000, pp. 216-240.

3. Villela WV and Barbosa RM, Repesando as relações entre gênero e sexualidade..., in: Parker RG and Barbosa RM, eds., Sexualidades Brasileiras, Rio de Janeiro, Brazil: Relume Dumará, 1996, pp. 189_ 199.

4. Ibid.

5. Heise L, Moore K and Toubia N, Sexual Coercion and Reproductive Health: A Focus on Research, New York: Population Council, 1995.
6. Diniz SG et al., Not like our mothers: reproductive choice and the emergence of citizenship among Brazilian rural workers, domestic workers and housewives, in: Petchesky RP and Judd K, eds., Negotiating Reproductive Rights: Women's Perspectives Across Countries and Cultures, New York: Zed Books, 1998, pp. 31-68.

7. Villela WV and Barbosa RM, 1996, op. cit. (see reference 3).

8. Sociedade Civil Bem Estar Familiar No Brasil (BEMFAM), Adolescentes, Jovens e a Pesquisa Nacional Sobre Demografia e Saúde: Um Estudo Sobre Fecundidade, Comportamento Sexual e Saúde Reprodutiva, Rio de Janeiro, Brazil: BEMFAM, 1999.

9. Manzelli H, Cómo un juego: la coerción sexual desde los varones adolescentes en Buenos Aires, in: Pantelides EA and López EM, eds., La Investigación Reciente Sobre Aspectos Socioculturales de la Salud Reproductiva de los Varones en América Latina, Buenos Aires, Argentina: Paidós, 2005.

10. BEMFAM, 1999, op. cit. (see reference 8).

11. Gregg JL, Virtually Virgins: Sexual Strategies and Cervical Cancer in Recife, Brazil, Stanford, CA, USA: Stanford University Press, 2003; and Goldstein DM, Laughter out of Place: Race, Class, Violence, and Sexuality in a Rio Shantytown, Berkeley, CA, USA: University of California Press, 2003

12. Rebhun LA, The Heart Is Unknown Country: Love in the Changing Economy of Northeast Brazil, Stanford, CA, USA: Stanford University Press, 1999.

13. Caravelas L, O Que os Homens Fazem e Pensam Sobre Sex, Recife, Brazil: Editora Universitaria da Universidade Federal de Pernambuco, 1994.

14. Goldstein DM, 2003, op. cit. (see reference 11).

15. Zanotta Machado L, Masculinidades, sexualidade e estupro: as construções da virilidade, Cadernos Pagu, 1998, 97(1):231-273.

16. Jejeebhoy SJ and Bott S, Non-Consensual Sexual Experiences of Young People: A Review of Evidence from Developing Countries, New Delhi, India: Population Council, 2003.

17. Heise L, Moore K and Toubia N, 1995, op. cit. (see reference 5)

18. Joint United Nations Program on HIV/AIDS (UNAIDS), 2004 Report on the Global AIDS Epidemic, New York: UNAIDS, 2004.

19. Registro Nacional de Patologia Tumoral, Diagnosticos de Câncer, Brasil: 1981-1985, Rio de Janeiro, Brazil: Instituto Nacional de Câncer, 1991

\section{RESUMEN}

Contexto: Creencias enraizadas en la cultura sobre el papel que les corresponde a los géneros influyen en el comportamiento sexual de la mujer y en su capacidad para protegerse de experiencias de relaciones sexuales no deseadas. El estudio de las creencias que influyen en el comportamiento de la mujer en su debut sexual asiste a contextualizar las relaciones sexuales no deseadas.

Métodos: En 2002, se realizaron 24 grupos focales para estudiar la experiencia de las mujeres en el momento de su primera actividad sexual. Las participantes eran de 18-21 y de 30-39 años y tenían ingresos bajos y medios; fueron reclutadas de lugares públicos y privados en dos ciudades del Brasil—Recife, la capital de Pernambuco, y Belo Horizonte, la capital de Minas Gerais. Los datos fueron analizados con respecto a temas comunes, y se escogieron declaraciones para ilustrar estos temas. Resultados: Las participantes en los grupos focales percibieron que los hombres tenían una necesidad urgente de mantener relaciones sexuales. Esta percepción llevó a que las mujeres temieran a enfrentarse al abandono, el enojo o la violencia de la pareja si se rehusaran a mantener relaciones. Las participantes 
creían que en el momento de su primera experiencia sexual, la mujer debe actuar en forma pasiva porque si toma la iniciativa (por ejemplo, si le sugiere a su pareja usar un anticonceptivo) su pareja puede acusarle de ya haber iniciado la actividad sexual. Asimismo, creían que en cualquier circunstancia, las mujeres siempre deberían negarse a mantener relaciones sexuales para proteger así su reputación.

Conclusiones: Para reducir los casos de relaciones sexuales no deseadas, las intervenciones deberán abordar las expectativas sociales que conforman la conducta sexual del hombre y la mujer.

\section{RÉSUMÉ}

Contexte: Les croyances culturelles relatives aux rôles sexuels influencent le comportement sexuel des femmes et leur aptitude à se protéger contre les expériences sexuelles non désirées. Létude des croyances qui influencent le comportement des femmes à l'heure de leur initiation sexuelle aide à contextualiser les rapports sexuels non désirés.

Méthodes: Vingt-quatre groupes de discussion sur l'expérience féminine de l'initiation sexuelle ont été organisés en 2002 avec des femmes de faibles et moyens revenus âgées de 18 à 21 ans et de 30 à 39 ans, recrutées dans des endroits publics et privés de Recife, capitale de Pernambuco, et de Belo Horizonte, ca- pitale de Minas Gerais, au Brésil. Les données ont été analysées en fonction de leurs thèmes communs, avec sélection de citations pour illustrer ces thèmes.

Résultats: Les participantes aux groupes de discussion percevaient chez les hommes un besoin impérieux de rapports sexuels. Cette perception amenait les femmes à craindre l'abandon, la colère ou la violence si elles refusaient les avances sexuelles de leur partenaire. Les participantes pensaient que les femmes doivent se montrer passives lors de leurs premiers rapports sexuels, car la prise d'initiative (demander au partenaire de pratiquer la contraception, par exemple) mènerait à l'accusation, par leur partenaire, d'une expérience sexuelle antérieure. Les participantes croyaient aussi qu'il leur fallait dire non aux rapports sexuels en toutes circonstances pour protéger leur réputation. Conclusion: Pour réduire les rapports sexuels non désirés, les interventions doivent tenir compte des attentes sociales qui façonnent le comportement sexuel des hommes et des femmes.

\section{Acknowledgments}

The author gratefully acknowledges Joseph E. Potter, Jacqueline Thomas and the support of the Andrew W. Mellon Foundation, which provided funding for this research.

Author contact:amoore@guttmacher.org

\section{Acknowledgment to Reviewers}

The editors wish to express their appreciation to the following reviewers for their assistance in evaluating material for International Family Planning Perspectives in 2005:

\begin{tabular}{ll} 
Carla AbouZahr & Minja Kim Choe \\
Mohamed M. Ali & John G. Cleland \\
Fred Arnold & Ann L. Coker \\
Mohamed Ayad & Márcia Thereza Couto \\
Stella Babalola & Anne R. Cross \\
Patricia E. Bailey & Yvette Cuca \\
Jennifer Barber & Soledad Díaz \\
Trude A. Bennett & Megan Douthwaite \\
Ruth Bessinger & Parfait Eloundou-Enyegue \\
Ann E. Biddlecom & Annabel S. Erulkar \\
Kelly Blanchard & Richard Fehring \\
Lisa Bohmer & Delicia Ferrando \\
Lisanne F. Brown & James R. Foreit \\
Josefina V. Cabigon & Alfredo L. Fort \\
Martha Campbell & Duff Gillespie \\
\hline
\end{tabular}

$\begin{array}{ll}\text { Sally J. Guttmacher } & \text { Saroj Pachauri } \\ \text { Angela Heimburger } & \text { Arvind Pandey } \\ \text { Terence H. Hull } & \text { David H. Peters } \\ \text { Barbara Janowitz } & \text { Chai Podhisita } \\ \text { Eric R. Jensen } & \text { Saumya Ramarao } \\ \text { J. Timothy Johnson } & \text { Zeba A. Sathar } \\ \text { Heidi E. Jones } & \text { Iqbal H. Shah } \\ \text { Andrzej Kulczycki } & \text { Ilene S. Speizer } \\ \text { Jan Kumar } & \text { Joseph B. Stanford } \\ \text { Joe L. Lugalla } & \text { Etienne Van de Walle } \\ \text { Nyovani J. Madise } & \text { Christine Varga } \\ \text { Joanne E. Mantell } & \text { Cindy Waszak Geary } \\ \text { M. Catherine Maternowska } & \text { Susan C. Weller } \\ \text { Eleanor Maticka-Tyndale } & \\ \text { James F. McCarthy } & \end{array}$

